\title{
10-14 Yaş Grubu Çocukların Empati Kurma ve Hoşgörülü Olma Becerilerinin Obez Akranlarına Karşı Tutumlarına Etkisi
}

\section{The Effects of Empathy and Tolerance Skills of 10-14 Age Group Children on Attitudes towards Obese Peers}

\author{
${ }^{1}$ Safiye ÇATALÇAM, ${ }^{2}$ Müge SEVAL
}

\begin{abstract}
${ }^{1}$ Zonguldak Bülent Ecevit Üniversitesi, Sağlık Bilimleri Enstitüsü Çocuk Sağlığı ve Hastalıkları Hemşireliği Anabilim Dalı, TÜRKIYYE ${ }^{2}$ Zonguldak Bülent Ecevit Üniversitesi, Sağlık Bilimleri Fakültesi Hemşirelik Bölümü, Çocuk sağlığı ve Hastalıkları Hemşireliği Anabilim
\end{abstract} Dalı, TÜRKIYYE

\section{ÖZ}

Amaç: 10-14 yaş çocukların hoşgörülü olma ve empati kurma becerisinin obez akranlarına tutumlarına etkisinin değerlendirilmesi amaçlanmıştır.

Materyal ve Metot: Zonguldak'da 380 ögrenciyle tanımlayıcı nedensel karşılaştırma çalışması olarak gerçekleştirilmiştir. Veriler "Çocuğa ilişkin Bilgi Formu", "Çocuklar ve Ergenler ilişkin Empati”, "Hoşgörülü Davranış" ve "Obez Çocuklara Yönelik Tutum" ölçekleri ile toplanmıștır. Analizlerde SPSS Statistics 22 programı kullanılmıştır. Bulgular: Empatik ve hoşgörülü davranma becerileri arttıkça obez akranlarına yönelik tutumlarında $(r=0,20$ ve $r=0,33$ ) olumlu yönde artı̧̧ belirlenmiştir.

Sonuç: $10-14$ yaş ortaöğretim öğrencilerinin hoşgörülü olma ve empati kurma becerisinin obez akranlarına yönelik tutumları üzerinde etkili olduğu sonucuna varılmıştır. Anahtar Kelimeler: Çocuk, empati, hoşgörü, obezite, tutum

\section{ABSTRACT}

Objective: The aim was to evaluate the effect of tolerance and empathy skills of 10-14 age group students on attitudes towards obese peers.

Materials and Methods: It was carried out with 380 students in Zonguldak as a descriptive causal comparison study. "Information Form on Child", "Empathy for Children and Adolescents", "Tolerant Behavior" and "Attitude for Obese Children" scales were used for data collection. SPSS Statistics 22 program was used for analysis.

Results: As the empathic and tolerant behavior skills increased, attitudes towards obese peers $(\mathrm{r}=0.20$ and $\mathrm{r}=$ 0.33 ) increased positively.

Conclusion: The tolerance and empathy skills of 10-14 year-old secondary school effect their attitudes towards obese peers.

Keywords: Attitude, child, empathy, obesity, tolerance

\section{Yayın Bilgisi / Article Info:}

Gönderi Tarihi/ Received: 27/02/2021

Kabul Tarihi/ Accepted: 01/04/2021

Zonguldak Bülent Ecevit Üniversitesi Sağlık Bilimleri Fakültesi

Çocuk Sağlı̆̆ı ve Hastalıkları Anabilim, Esenköy Mah. Abaz Cad.

Ahmet Erdoğan Sağlık Hizmetleri Meslek Yüksekokulu Binası 4

Online Yayın Tarihi/ Published: 05/06/2021

Kat Kozlu/ZONGULDAK

Tel: +90 5053037481

E-mail: sevalmuge@gmail.com

Atıf / Cited: Çatalçam S, Seval M. 10-14 Yaş Grubu Çocukların Empati Kurma ve Hoşgörülü Olma Becerilerinin Obez Akranlarına Karşı Tutumlarına Etkisi. Online Türk Sağllk Bilimleri Dergisi 2021;6(2):272-281. doi: 10.26453/otjhs.887602

\section{GíRİs}

Dünya Sağlık Örgütü (World HealthOrganizationWHO), 2019 yılı verilerinde göre beş yaş altındaki kilolu ve obez çocukların sayısının 38 milyonun üzerine çıktığını ve yaşı 5-19 yaş arası kilolu çocuklarınsayısının 340 milyonu geçtiği rapor edilmiştir. ${ }^{1,2}$ Günümüzde çocukluk çağı obezitesi, fizyo- lojik etkileri yanı sıra çocuğun ve gencin psikolojik, sosyal ve sprituel dengesini de bozan birhalk sağlığg sorunu olarak kabul edilmektedir. Bunun yanı sıra obezite nedeniyle meydana gelen beden imajındaki farklılıkların akran gruplarında dişlanma ve etiketlenme ile çocukta/gençte öz güven ve öz değer sorunlarını beraberinde getirmektedir. ${ }^{3,4}$ 
Çocuklar ve gençler, kendisi gibi olmayan obez akranını, günlük etkileşimlerinde ve sosyal medya ortamında yetersiz ilan edip yok sayarak önyargılı, ayrımcı ve etiketleyici bir tutumla yaklaşabilmektedir. $^{5-9}$ Akranları tarafindan etiketleme obez çocuklarda/gençlerde saldırganlık ve akran zorbalılığına maruz kalma/maruz bırakma, gibi davranış problemlerini de beraberinde getirebilmektedir. ${ }^{10}$

Söz konusu olumsuz tutumların değiştirilmesinde insani değerlerin farkındalığının arttırılması yararlı olabilmektedir. Değerleri güçlenen çocuk ve genç önyargısız iletişim kurabilme becerisini de geliştirebilmektedir. Değerler sistematiğinde "empati kurma" ve "hoşgörülü davranma" da tutum değişikliğini destekleyen ve birbirini bütünleyen en önemli iki insani değerdir. ${ }^{11}$ Empati, "bir kişinin kendisini karşısındakinin yerine koyarak duruma onun bakış açısı ile bakması, o kişinin duygularını ve düşüncelerini doğru olarak anlaması, hissetmesi ve bu durumu ona iletmesi sürecidir" şeklinde tanımlanmıştır. ${ }^{1}$ Hoşgörü, karşılıklı anlayış ve yaşam şeklidir. ${ }^{12}$ Özellikle bu iki değerin farkındalığının arttırılması çocuğun kendisinden farklı olan akranı anlamasına ve ön yargisız olarak kabul etmesine yardım ederek olumlu tutum geliştirmesine yardımcı olabilmektedir. ${ }^{11-13}$ Yukarıda sunulan teorik çerçevede bu araştırmada, 10-14 yaş grubu öğrencilerin empati kurma ve hoşgörülü davranma düzeylerinin obez akranlarına yönelik tutumlarına etkisini değerlendirmesi amaçlanmıştır.

\section{MATERYAL VE METOT}

Araştırma için Zonguldak Bülent Ecevit Üniversitesi İnsan Araştırmaları Etik Kurulu'ndan (Tarih: 08.05.2019, karar no:583) etik izin, Kozlu Milli Eğitim Müdürlüğü'nden kurum izinleri ve katılmayı kabul eden öğrencilerden aydınlatılmış onam alınmıştır. Araştırmada kullanılan ölçekler için ölçek sahiplerinden izin alınmıştır.

Araştırma Tipi: Araştırma "tanımlayıcı nedensel karşılaştırma çalışması” olarak Zonguldak İli Kozlu İlçe Milli Eğitim Müdürlüğü'ne bağlı bir ortaokulda Mayıs-Aralık 2019 tarihleri arasında gerçekleştirilmiştir.

Araştırmanın Evren ve Örneklem: Evrenin örneklem kabul edildiği araştırmada, katılmayı kabul eden 380 öğrenci araştırmaya dahil edilmiştir.

Araştırmanın Veri Toplama Formları: Veriler "Çocuğa İlişkin Bilgi Formu', "Çocuklar ve Ergenler İçin Empati Ölçeğì", "Hoşgörülü Davranış Ölçeği” ve "Obez Çocuklara Yönelik Tutum Ölçeğii” ile toplanmıştır.

Çocuğa İlişkin Bilgi Formu: Bu formda; çocuğa ve anneye dair açık ve kapalı olmak üzere 15 soru yer almaktadır.

Çocuklar ve Ergenler İçin Empati Ölçeği: Çocuklar ve Ergenler İçin Empati Ölçeği (ÇEEÖ), Türkçe uyarlaması Gürtunca tarafindan 8-14 yaş arasındaki çocuklarla yapılmıştır. ${ }^{14,15}$ Ölçeğin puanlanması 1-0 şeklindedir. Her evet cevabı için "1", her hayır cevab1 için ise " 0 " puan verilir. Ölçekten alınan yüksek puan empati becerisinin yüksek olduğunu göstermektedir. Ölçeğin bu araştırmada güvenirliği için hesaplanan KR-20 güvenirlik katsayısı 0,68 olarak bulunmuştur.

Hoşgörü̈lü Davranış Ölçeği: “Hoşgörülü Davranış Ölçeği”, Erken tarafından geliştirilmiştir. ${ }^{11}$ Ölçek 13 madde ve iki alt boyuttan oluşmaktadır. Ölçek "her zaman” ve hiçbir zaman” aralığında 5'li likert tipi, özbildirime dayalı bir ölçektir. Birinci alt boyutu olan "başkalarının yanlışlarına ve tercihlerine tahammül gösterme" alt boyutu $(1,2,3,5,8,9,10,12) 8$ maddeden oluşmaktadır. İkinci alt boyut olan "çevresindekilere anlayışlı davranma" alt boyutu ise $(4,6,7,11,13)$ beş maddeden oluşmaktadır. Ölçekte 13 ile 65 arasında puan alınmaktadır. Yüksek puanlar hoşgörülü davranma düzeyinin yüksekliğini göstermektedir. Ölçeğin sırasıyla alt boyutlarına ilişkin Cronbach Alfa iç tutarlılık katsayıları 0,77 ve 0,58 olarak bulunmuştur. Ölçeğin bütününe ilişkin güvenirlik ise 0,74 olarak bulunmuştur. $\mathrm{Bu}$ araştırmada ölçeğin bütününe ilişkin Cronbach alfa değeri 0,66 ; birinci alt boyut için 0,60 ; ikinci alt boyut için 0,61 olarak bulunmuştur.

Obez Çocuklara Yönelik Tutum Ölçeği: "Obez Çocuklara Yönelik Tutum Ölçeği” Balcı Çelik, Vural Batık, Özcan ve Aksoy tarafından geliştirilmiştir. ${ }^{16}$ Ölçek, 16 maddeden oluşan ve "kesinlikle katılmiyorum" ve "tamamen katıliyorum" arasında değişen 5'li likert tipi, özbildirime dayalı bir ölçektir. Ölçek iki boyutludur ve birinci alt boyut "obez akranı reddetme" adıyla 9 olumsuz maddeden oluşmaktadır. İkinci alt boyut "obez akranı kabul etme" adıyla 7 maddeden oluşmaktadır. Ölçekten alınacak puanlar 16 ile 80 puan arasında değişmektedir. Yüksek puan obez çocuklara yönelik olumlu tutumu, düşük puanlar ise olumsuz tutumu göstermektedir. Ölçeğin bütünün güvenirliğine ilişkin Cronbach Alfa iç tutarlılık katsayısı 0,76; birinci alt boyut için 0,83 ; ikinci alt boyut için ise 0.80 olarak bulunmuştur. ${ }^{16}$ Ölçeğin bu araştırmadaki güvenirliği 0,83; birinci alt boyut için 0,83 , ikinci alt boyut için 0,91 olarak bu- 
lunmuştur.

Uygulama: Araştırmanın veri toplama süreci başlamadan bir hafta önce kapalı zarf yöntemi ile "aydınlatılmış onam formu" ve çocuklar tarafından doldurulacak formlar velilere gönderilerek bilgilendirme yapılıp izin alınmıştır. İzin sürecinden sonra okul idaresinin belirlediği günler ve saatlerde veri toplama süreci başlatılmıştır. Veriler fiziksel ortamim daha uygun olması nedeniyle okulun spor salonunda toplanmıştır. Çocukların derslerinde aksama olmaması için genellikle beden eğitimi derslerinde veri toplanmıştır. Veri toplama formları öğrenciler tarafından doldurulmuş, anlamadıkları sorularda araştırmacı gerekli açıklama yapmıştır. Veri toplama formlarını dolduran öğrencilerin boyu ve kilosu ölçülerek araştırmacı tarafindan BKİ değerleri hesaplanmıştır.

Verilerin Değerlendirilmesi: Araştırmada t testi; tek yönlü varyans analizi (One-Way ANOVA) kullanılmıştır. Gruplar arası farkın kaynağının belirlenmesinde Scheffe testi kullanılmıştır. Empati düzeyi, hoşgörülü davranma düzeyi ve obez çocuklara yönelik tutum değişkenleri arasındaki ilişkilerin belirlenmesinde pearson momentler çarpımı korelasyonu katsayısı kullanılmıştır. Empati, hoşgörülü davranma düzeyleri veobez çocuklara yönelik tutum üzerindeki etkisi çoklu regresyon (step wise metodu) analizi belirlenmiştir. İstatistiksel anlamlılık düzeyi $\mathrm{p}<0,05$ olarak alınmıştır.

\section{BULGULAR}

Öğrencilerin \%49,2'si k1z, \%50,8'i erkek olduğu ve yarıdan fazlasının $(\% 28,7$ ve $\% 23,4)$ altıncı ve yedinci sınıf olduğu bulunmuştur. Beden Kitle İndeksi (BKI) düzeylerinde $\% 23,7$ 'sinin fazla kilolu ve \% 13,7 'sinin obez olduğu belirlemiştir. Kronik hastal1ğ1 olan $(\% 7,6)$ ve ailesinde kilo problemi olan $(\%$ 19,2) öğrencilerin oranının oldukça düşük olduğu saptanmıştır (Tablo 1).

K1z öğrencilerin empati $(t=6,32, p=0,00, p<0,05)$, hoşgörülü davranma ( $\mathrm{t}=3,49, \mathrm{p}=0,00, \mathrm{p}<0,05)$, başkalarının yanlışlarına ve tercihlerine tahammül etme $(\mathrm{t}=3,01, \mathrm{p}=0,00, \mathrm{p}<0,05)$ ve çevresindekilere anlayışlı davranma $(t=2,62, p=0,00, p<0,05)$ puanlarının erkek öğrencilere göre anlamlı düzeyde farklılık gösterdiği belirlenmiştir (Tablo 2). Bunun yanı sıra kronik hastalığı olmayan öğrencilerin obez çocuklara yönelik tutum genel puanlarının $(\mathrm{t}=-2,29, \mathrm{p}=0,02$, $\mathrm{p}<0,05)$ ve obez akranı reddetme alt boyut puanlar1nın $(\mathrm{t}=-2,09, \mathrm{p}=0,03, \mathrm{p}<0,05)$ anlamlı düzeyde farklılık gösterdiği saptanmıştır (Tablo 2 $)$.

Yaş gruplarına göre empati ve obez çocuklara karşı tutum ölçeği puan ortalamaları anlamlı düzeyde farklılık göstermezken, 9-10 yaş ve 11-12 yaş grubunda hoşgörülü davranma ölçeği başkalarının yanlışlarına ve tercihlerine tahammül gösterme alt boyut puanlarının 13-14 yaş grubuna göre farklılığın anlamlı düzeyde olduğu belirlenmiştir $(\mathrm{F}=4,58$, $\mathrm{p}=0,01, \mathrm{p}<0,05)$ (Tablo 3). Benzer şekilde beşinci ve altıncı sınıf ögrrencilerinin başkalarının yanlışlarına ve tercihlerine tahammül gösterme puanlarının yedinci ve sekizinci sınıflara göre anlamlı düzeyde farklılık gösterdiği saptanmıştır $(\mathrm{F}=2,72, \mathrm{p}=0,04$, $\mathrm{p}<0,05) \quad($ Tablo 3 $)$. Sınıf düzeyi yükseldikçe (sekizinci sınıf) obez akranı red etme alt boyut puanlarının anlamlı düzeyde farklılaştığı görülmüştür $(\mathrm{F}=3,38, \mathrm{p}=0,01, \mathrm{p}<0,05)$. BKI düzeylerine göre çok zayıf öğrencilerin hoşgörülü davranma ölçeği genel ile başkalarının yanlışlarına ve tercihlerine tahammül gösterme alt boyut puanlarının diğer BKI gruplarına göre anlamlı düzeyde farklılaştığı görülmüştür $(F=2,61, p=0,03, p<0,05)(F=2,74, p=0,02$, $\mathrm{p}<0,05)$ (Tablo 3).

Öğrencilerin empati düzeyleri ile hoşgörülü davranma $(\mathrm{r}=0,38)$, başkalarının yanlışlarına ve tercihlerine sayg1 gösterme $(\mathrm{r}=0,24)$, çevresindekilere anlayışlı davranma $(\mathrm{r}=36)$ ve obez çocuklara yönelik tutum $(\mathrm{r}=0,28)$ düzeyleri arasında pozitif, anlamlı ve orta düzeyde ilişki bulunmuştur. Diğer taraftan hoşgörülü davranma düzeyleri ile obez çocuklara yönelik tutum $(\mathrm{r}=0,36)$, obez akranını reddetme $(\mathrm{r}=0,20)$ ve obez akranını kabul etme $(\mathrm{r}=0,33)$ düzeyleri arasında pozitif, anlamlı ve orta düzeyde ilişki bulunmuştur (Tablo 4).

\section{TARTIŞMA VE SONUÇ}

Kız öğrencilerin empati puanlarının erkek öğrencilerin empati puanlarına göre farklılık gösterdiği bulunmuştur $(\mathrm{t}=6,32, \mathrm{p}<0,05)$ (Tablo 2). Hasta ve ark. ${ }^{17}$ üniversite ve Rehber ve Atıcı'nın ${ }^{18}$ ortaokul öğrencileri ile yaptığı çalışmada kız öğrencilerin erkek öğrencilere göre empatik davranma eğilimlerinin daha fazla olduğu bulunmuştur. Kızların nazik ve anlayış1, erkeklerin dik duruş sergilemesine yönelik sosyal beklentinin, erkeklerin empati puanlarının daha düşük çıktığı düşünülmektedir.

Yine kız öğrencilerin hoşgörülü davranma $(\mathrm{t}=3,49$, $\mathrm{p}<0,05)$ başkalarının yanlışlarına ve tercihlerine tahammül etme $(\mathrm{t}=3,01, \mathrm{p}<0,05)$ ve çevresindekilere anlayışlı davranma $(\mathrm{t}=2,62, \mathrm{p}<0,05)$ puanlarının erkek öğrencilere göre anlamlı düzeyde farklılık gösterdiği belirlenmiştir. Kalın ve Nalçacı'nın çalışmasında da kız öğrencilerin, erkek öğrencilere göre hoşgörü eğilimlerinin daha yüksek olduğu tespit 
edilmiştir. ${ }^{19}$ Empatiye benzer şekilde hoşgörünün de kadın cinsiyetle daha fazla özdeşleşmiş bir sosyal değer olması bu ve diğer araştırmalarda benzer yönde sonucun elde edilmesini sağladığı düşünülmüştür. Kronik hastalığı olmayan öğrencilerin obez çocuklara yönelik tutumlarının daha olumlu olduğu belirlenmiştir. Birinci alt boyut olan obez akranı reddetme alt boyutunda da gruplar arasında anlamlı farklılık olduğu görülmektedir $(\mathrm{t}=-2,09, \mathrm{p}<0,05)$ (Tablo 2). Keser ve ark. obezite, astım ve kardit gibi kronik hastalığı olan çocukların kronik hastalığı olmayan çocuklardan daha fazla duygusal sorunlar yaşadığını göstermiş ve aynı çalışmada akran sorunları açısından ise obezite ve astım sorunu olan çocukların kronik hastalığı olmayan çocuklardan daha fazla akran sorunu yaşadıkları bulunmuştur. ${ }^{28}$ Kronik hastalık, kişinin iradesi dışında gelişirken, obezite kişinin kendi tercihleri (yanlış beslenme ve yetersiz egzersiz) sonucu oluşan bir süreç olarak algılanmış olabilir. Bundan dolayı kronik hastalığı olan çocukların, obezitenin kişinin iradesi çerçevesinde geliştiğini düşünerek obez akranını reddeden tutum geliştirdiği düşünülmüştür.

Araştırmada, 9-10 yaş ve 11-12 yaş grubunda hoşgörülü davranma ölçeği başkalarının yanlışlarına ve tercihlerine tahammül gösterme alt boyut puanlar1nın 13-14 yaş grubuna göre anlamlı düzeyde farklılık gösterdiği belirlenmiştir $(\mathrm{F}=4,58, \mathrm{p}<0,05)$ (Tablo 3). 11-12 yaş grubu ön ergenlik çocuğu için diğer insanlarla bilgi alışverişinde bulunmak, takım içinde var olmak ve toplumun onayladığı davranışlar da bulunmak önemli olduğu için bu farkın oluştuğu düşünülmüştür.

Beşinci ve altıncı sınıf öğrencilerinin başkalarının yanlışlarına ve tercihlerine tahammül gösterme puanlarının yedinci ve sekizinci sınıflara göre anlamlı düzeyde farklılık gösterdiği saptanmıştır $(\mathrm{F}=2,72$, $\mathrm{p}<0,05$ ) (Tablo 3). Çalışkan ve Sağlam ${ }^{20}$ ve İnel ve Gökalp ${ }^{21}$ beşinci ve altıncı sınıfa devam eden ilköğretim öğrencilerinin hoşgörü düzeylerini yedinci ve sekizince sınıfa devam edenlerden daha yüksek bulunmuştur. Yaş itibariyle 13-14 yaş grubu çocuklardan oluşan sekizinci sınıflar ergenliğe ilişkin duyarsızlık, olumsuz tutum, reddetme, kafa tutma ve risk alma gibi bulguların sıklıkla yaşandığı bir gruptur ki elde edilen sonuçlar beklendik düzeydedir.

Sınıf düzeyi yükseldikçe (sekizinci sınıf) obez akranı reddetme tutumunda artış olduğu belirlenmiştir $(\mathrm{p}<0,05)$ (Tablo 3). Durente'ye ${ }^{22}$ göre ilkokul üçüncü sınıfa giden çocukların beşinci sınıftakilere, Öztürk ve Alpkaya'nın ilkokul öğrencilerinin hem obez çocuklara hem de zayıf çocuklara olumsuz tutum sergiledikleri belirlenmiştir. ${ }^{23}$

Njelekela ve ark. ilkokul öğrencilerinin obezite bilgisinin olumlu seviyede olmasına rağmen ve obeziteye karşı olumsuz tutum içinde olduğu tespit edilmiştir. ${ }^{24}$ Alpkaya ve Çoknaz ise lise ögrencilerinin obez akranlarına yönelik tutumu orta düzeyde olumlu olarak değerlendirmiştir. ${ }^{25}$ Ergenlik dönemi çocukların kendisinden farklı olan arkadaşlarına karşı acımasız ve daha az hoşgörülü olduğu düşünüldüğünde, obez çocukların karşılaştığı tepkilerin alay etmeden akran zorbalığına kadar geniş bir yelpazeye yayılabilme potansiyeli olduğu düşünülmektedir.

BKİ'ye göre, çok zayıf öğrencilerin başkalarının yanlışlarına ve tercihlerine tahammül gösterme becerilerinin diğer gruplara göre daha iyi olduğu belirlenmiştir ( $p<0,05$, Tablo 3 $)$. Önder ve arkadaşlarına göre, obez çocuklarda psikolojik sorun görülme oranı yükselirken benlik saygısı düşmektedir. ${ }^{26}$ Köç ve Duygu yabancı uyruklu ortaokul öğrencilerinde, fiziksel ve duygusal açıdan farklılık gösteren ergenlerle alay edilme ve dışlanma oranının anlamlı düzeyde daha yüksek olduğu belirlemiştir. ${ }^{27}$ Ergenler için obezite zayıf olmaya göre daha travmatik ve dışlanması gereken bir durum olduğu düşünülmektedir. Şöyle ki, son 20 yıldır sosyal medyanın da özendirmesi ise Y kuşağının sonları ve günümüzün ergenlerini oluşturan $\mathrm{Z}$ kuşağında zayıf olmak olmazsa olmaz bir kabul kriteri haline gelmiştir. Ergenlik dönemi çocukların kendisinden farklı olan arkadaşlarına karşı acımasız ve daha az hoşgörülü olduğu düşünüldüğünde, obez çocukların karşılaştığı tepkilerin alay etmeden başlayıp akran zorbalığına varacak kadar geniş bir yelpazeye yayılabilme potansiyeli olduğu düşünülmektedir.

Öğrencilerin empati ve hoşgörülü davranma düzeyi arttıkça, obez çocuklara yönelik tutum düzeylerinde olumlu yönde anlamlı bir artış meydana geldiği belirlenmiştir (Tablo 4). Boyacı ve Ersever hoşgörü eğitimi alan öğrencilerinde akran zorbalığı puanlarının düştüğünü ancak eğitimlere ara verildiğinde zorbalık puanlarının arttığını tespit etmiştir. ${ }^{29}$ Eğitimin obez bireylere karşı tutumda olumlu etkileri olduğunu gösteren bir çalışma da Uluöz'ün Beden Eğitimi Yüksek Okulu öğrencileri ile yaptığı çalışmadır. Buna göre lisans eğitimleri sırasında aldıkları obeziteyle doğrudan ya da dolaylı olarak ilişkili dersler aracılığı ile obezitenin oluş mekanizması ile ilgili bilgi sahibi olmaları fazla kilolu ve obez bireylere karşı tutumlarını olumlu yönde değiştirmiştir. ${ }^{30}$ Obezite gibi kronik durumlarda çocuğun ve çevresinin duygu ve düşünce örüntüleri farklılaşmaktadır. Çocuk kendini kurban psikolojisine geçirip her türlü 
olumsuzluğu yaşamaya layıkmış gibi hissetmektedir. Kurban psiklolojisinin yansıttığı düşük enerji, karşısındaki bireylerin olumsuz tepkilerini kendine çeken bir döngü oluşturmaktadır. Bu zinciri kırmanın temel noktası olumlu enerjinin ortaya çıkmasını sağlayan empati, saygı ve hoşgörü duygularının daha fazla deneyimlenmesinin desteklenmesidir. Çekim yasasına göre, evrenin iyilik/kötülük (yin/yang) dengesinin devamlılığının olumlu yönde sürdürülebilmesi için olumsuz duyguların özgür bırakılıp olumlu duyguların yerine gelmesine izin vermek gerekir. Sağlıklı çocukların obezite gibi farklılıkları olan çocukları kabul edebilmesi için de empati ve hoşgörü gibi olumlu duyguları açığa çıkaran değerlerle karşı karŞıya bırakılması önemlidir.

Bu bağlamda araştırmada kızların empati ve hoşgörü düzeyinin daha fazla olduğu, kronik hastalığı olmayanların obez akranlarına karşı daha olumlu tutum sergilediği, sınıf düzeyi arttıkça obez akranı reddetme düzeyinin arttığı, çok zayıf olanlar obez akranlarına karşı daha pozitif ayrımcı (benzer problemi zıt kutuplarda yaşadıkları için) olduğu, öğrencilerin empatik ve hoşgörülü davranma becerileri arttıkça obez çocuklara yönelik tutum olumlu yönde arttığ1 sonuçlarına ulaşılmıştır.

$\mathrm{Bu}$ sonuçların olumlu yönlerini arttırabilmek için, değerler sistemini bütüncül yaklaşımla ele alan calışmalar planlanması önerilebilir. Bunun yanı sıra bir halk sağlığı sorunu olan obeziteye aile, okul ve sağlık ekibi işbirliği ile çözüm bulabilecek projelerin gerçekleştirilmesi bir diğer öneridir. Çocuklar ve aileler için obezite farkındalığını artırmaya ve önlenmesine yönelik beslenme, egzersiz, başa çıkma becerileri gibi konularda eğitimlerin gerçekleştirilmesinin de yararlı olabileceği düşünülmektedir. Bu bağlamda akran zorbalığı, duygusal mobing ya da etiketlenme sürecinin önlenmesinde okul hemşiresi olarak görev yapan bir çocuk hemşiresinin aile ve okul iş birliği ile gerçekleştireceği girişimler önemli olabilir.

Araştırmanın pilot okul olan tek okulda gerçekleştirilmesi ve belirli yaş aralığında gerçekleştirilmiş olması bu çalışmanın sınırlılığıdır.

Etik Komite Onayı: Araştırmamız Zonguldak Bülent Ecevit Üniversitesi İnsan Araştırmaları Etik tarafindan onayland 1 (Tarih: 08.05.2019, karar no:583).

Çıkar Çatışması: Yazarlar çıkar çatışması bildirmemektedir.

Yazar Katkıları: Fikir-MS; Denetleme-MS; Malzemeler-SÇ; Veri toplanması ve/veya işlemesi-MS,SÇ;
Analiz ve/veya yorum-MS,SÇ; Yazıyı yazanMS,SÇ.

Hakem değerlendirmesi: Dış bağımsız.

\section{KAYNAKLAR}

1. World Health Organisation. Obesity and Overweigt 2020. https://www.who.int/news-room/fact -sheets/detail/obesity-and-overweight. Erişi tarihi 30 Haziran 2020.

2. Yılmaz M, Ağatıŏglu Kundakçı G, Dereli F, Özgüven Tornacı B, Egelioğlu Cetişli N. İlköğretim öğrencilerinde yaş ve cinsiyete göre obezite ve ilişkili özellikler obezite ve ilişkili faktörler. The Journal of Current Pediatrics. 2019;17 (1):127-140.

3. Kalkım A, Ergül Ş. Önemli bir kronik hastalık: Çocukluk ve ergenlik döneminde obezite. TAF Preventive Medicine Bulletin. 2011;10(2):223230.

4. Kılıçarslan S, Sanberk İ. Ergen bireylerin benlik saygısı, beden kitle endeksi veyaşam kalitesi ilişkisinin incelenmesi. Journal of Human Sciences. 2016;13(2):3211-3230.

5. Koç N, Bülbül FS, Akıncı N, Yıldız KC, Bölükbaş Ş. Obez çocukların anne/babalarının beden kitle indeksleri beden algılarını etkiler mi? Ankara Sağlık Bilimleri Dergisi. 2018;(2):11-20.

6. Ercan A, Akçil OK, Kızıltan G, Altun S. Sağlık bilimleri öğrencileri için obezite önyarg1 ölçeğinin geliştirilmesi: Gams 27-Obezite Önyarg1 Ölçeği. Uluslararası Hakemli Beslenme Araştırmaları Dergisi. 2015;3(2):29-43. doi:10.17362/Dbhad.2015 310322

7. Uyanık G, Yılmaz M, Şahin A. Sağlık bilimleri öğrencilerinin obezite ile ilgiliön yargılarının belirlenmesi. Genel Sağlık Bilimleri Dergisi. 2020;1(2):48-58.

8. Knafo H. The development of body image in school-aged girls: A review of the literature from sociocultural, social learning theory, psychoanalytic, and attachment theory perspectives. New School Psychological Bulletine. 2016;13(2):1-16.

9. Ünal D. Sağlık çalışanlarının obez bireylere karşı tutumlarının değerlendirilmesi. Başkent Üniversitesi Sağlık Bilimleri Enstitüsü Beslenme ve Diyetetik Anabilim Dalı, Yüksek Lisans Tezi. Ankara, Türkiye. 2018.

10. Tas D, Tüzün Z, Düzçeker Y, Akgül S, Kanbur $\mathrm{N}$. The effects of parental and peer factors on psychiatric symptoms in adolescents with obesity. Eat Weight Disorder. 2020;(25):617-625. doi:10.1007/s40519-019-00660 
11.Erken M. Empati becerisinin ahlaki davranıslar üzerindeki etkisi. Sakarya Üniversitesi Sosyal Bilimler Enstitüsü Eğitim Bilimleri ABD, Yüksek Lisans Tezi. Sakarya, Türkiye. 2009.

12.Dökmen Ü. İletişim Çatışmaları ve Empati Sanatta ve Günlük Yaşamda. İstanbul: Remzi Kitapevi; 2019.

13. Gökler R. Empatik eğilim ölçeğinin ilkögretim sekizinci sınıflar için uyarlanması. Aile ve Toplum Egitim-Kültür ve Araştırma Dergisi. 2009;7(25):77-86.

14. Bryant BK. An index of empathy for children and adolescents. Child Development. 1982;53:413-425.

15. Gürtunca A. Çocuklar ve ergenler için empati ölçeği Türkiye geçerlik ve güvenirlik çalışması. Arel Üniversitesi Sosyal Bilimler Enstitüsü Psikoloji Programı, Yüksek Lisans Tezi. İstanbul, Türkiye. 2013.

16. Çelik Balcı S, Vural Batik M, Özcan K, Aksoy S. Çocuklara yönelik tutum ölçeği: Geçerlik ve güvenirlik çalışması. e-International Journal of Educational Research. 2015;6(1):40-53.

17. Hasta D. Saldırganlık: kişilerarası ilişki tarzları ve empati açısından bir inceleme. Ankara Üniversitesi Sosyal Bilimler Enstitüsü Dergisi. 2013;4(1):64-90.

18. Rehber E, Atıcı M. İlköğretim ikinci kademe öğrencilerinin empatik eğilim düzeylerine göre çatışma çözme davranışlarının incelenmesi. Çukurova Üniversitesi Sosyal Bilimler Enstitüsü Dergisi. 2009;18(1):323-342.

19. Kalın ZT, Nalçacı A. Ortaokul 5. Sınıf Öğrencilerinin Hoşgörü Eğilimlerinin Çeşitli Değişkenler Açısından İncelenmesi. Bayburt Eğitim Fakültesi Dergisi. 2017;12(23):293-304.

20. Çalışkan H, Sağlam Hİ. Hoşgörü eğilim ölçeğinin geliştirilmesi ve ilköğretim öğrencilerinin hoşgörü eğilimlerinin çeşitli değişkenler açısından incelenmesi. Kuram ve Uygulamada Eğitim Bilimleri Dergisi. 2012;12(2):1431-1446.

21. İnel Y, Gökalp A. Ortaokul öğrencilerinin hoşgörü eğilimlerinin incelenmesi. Turkish Studies Educational Sciences. 2018;13(27):847-848. doi:10.7827/TurkishStudies. 14380

22. Duranta F, Fasolo M, Mari S, Mazzola AF. Children's attitudes and stereotype content toward thin, average-weight, and overweight peers. SAGE Open. 2014;(2):1-11. doi:10.1177/ 2158244014534697

23. Öztürk Y, Alpkaya U, Keskin K, Çubuk A. 1113 yaş çocukların beslenme davranışları ile obez akranlarına yönelik tutumları arasındaki ilişkinin incelenmesi. Journal of International Social Research. 2017;10(53):622-626. doi:10.17719/ jisr.20175334150

24. Njelekela MA, Muhihi A, Mpembeni RNM. Knowledge and attitudes towards obesity among primary school children in Dar es Salaam, Tanzania. NigerianMedical Journal of the NigeriaMedical Association. 2015;56(2):103-108. doi:10.4103/0300-1652.150692

25. Alpkaya U, Çoknaz H. Lise öğrencilerinin beden eğitimi dersi tutumlarının, obez akran tutumlarının karşılaştırılması ve arasındaki ilişkinin incelenmesi. Uluslararası Sosyal Araştırmalar Dergisi. 2018;11(57):374-380.

26. Önder A, Kavurma C, Çelmeli G, Adanır Sürer A, Özatalay E. Obezite tanılı çocuk ve ergenlerde psikopatoloji, yaşam kalitesi ve ebeveyn tutumlarının değerlendirilmesi. İzmir Dr. Behçet Uz Çocuk Hastanesi Dergisi. 2018;8(1):51-58.

27. Köç A, Duygu H. Ortaokul öğrencilerinin farklılıklara saygı değerini edinimleri ve yabancı uyruklu öğrencilerle uyum becerileri. Journal of Innovative Research in Social Studies. 2018;1 (1):38-50.

28. Keser N, Kapçı Gül E, Odabaş E. Farklı kronik hastalığı olan ve olmayan çocukların benlik algısı, duygusal-davranışsal sorunlar ve ana-baba tutumları açısından karşılaştırılması. Çocuk ve Gençlik Ruh Sağlığı Dergisi. 2012;19(2):57-65.

29. Boyacı M, Ersever OG. Hoşgörü eğilimi geliştirme programının 5. sınıf öğrencilerinin hoşgörü ve zorbalık düzeylerine etkisi. Eğitim ve Bilim. 2017;42(189):167-182.

30.Uluöz E. Beden eğitimi ve spor yüksekokulu ögrrencilerinin obez bireylere karşı tutum düzeylerinin sınıf değişkenine ve bazı değişkenlere göre karşılaştırılması. Uluslararası Spor, Egzersiz ve Antrenman Bilimi Dergisi. 2016;2(4):124136. 
Tablo 1. Öğrencilerin tanımlayıcı özelliklerin dağılımı.

\begin{tabular}{|c|c|c|c|}
\hline Değişkenler & Kategoriler & $\mathbf{n}$ & $\%$ \\
\hline \multirow[t]{2}{*}{ Cinsiyet } & Kiz & 187 & 49,2 \\
\hline & Erkek & 193 & 50,8 \\
\hline \multirow{3}{*}{ Yaş } & $9-10$ yaş & 54 & 14,2 \\
\hline & $11-12$ yaş & 196 & 51,6 \\
\hline & $13-14$ yaş & 130 & 34,2 \\
\hline \multirow{4}{*}{ Sinıf } & 5. Sinif & 60 & 15,8 \\
\hline & 6. Sinif & 109 & 28,7 \\
\hline & 7.Sinıf & 89 & 23,4 \\
\hline & 8.Sinif & 122 & 32,1 \\
\hline \multirow{5}{*}{ BKİ } & Çok zayif & 30 & 7,9 \\
\hline & Zayıf & 46 & 12,1 \\
\hline & Normal & 162 & 42,6 \\
\hline & Fazla kilolu & 90 & 23,7 \\
\hline & Obez & 52 & 13,7 \\
\hline \multirow{2}{*}{ *Kronik Hastalık } & Var & 29 & 7,6 \\
\hline & Yok & 351 & 92,4 \\
\hline \multirow[t]{2}{*}{ Ailede Kilo Problemi Olan Birey } & Var & 73 & 19,2 \\
\hline & Yok & 307 & 80,8 \\
\hline
\end{tabular}

*: Çocukların Kronik Hastalık (Tip 1 DM: 2; Hipertansiyon: 1; Tiroit bozuklukları: 8; Astım: 9; Epilepsi: 1; Hastalı̆̆ını bilmeyen: 8). 
Tablo 2. Öğrencilerin empati, hoşgörülü davranma ve obez çocuklara yönelik tutumlarının cinsiyete ve kronik hastalık varlığına göre karşılaştırılması.

\begin{tabular}{|c|c|c|c|c|c|c|}
\hline Ölçekler & Cinsiyet & $\mathbf{n}$ & $\overline{\mathrm{X}}$ & Ss. & $\mathbf{t}^{\mathbf{a}}$ & $\mathbf{p}^{\mathbf{a}}$ \\
\hline \multirow[t]{2}{*}{ Empati } & $\mathrm{K}_{1 \mathrm{Z}}$ & 187 & 14,82 & 3,31 & \multirow[t]{2}{*}{6,32} & \multirow[t]{2}{*}{0,00} \\
\hline & Erkek & 193 & 12,74 & 3,10 & & \\
\hline \multirow[t]{2}{*}{ Hoşgörülü Davranma } & $\mathrm{K} 1 \mathrm{Z}$ & 187 & 4,38 & 0,50 & \multirow[t]{2}{*}{3,49} & \multirow[t]{2}{*}{0,00} \\
\hline & Erkek & 193 & 4,20 & 0,54 & & \\
\hline \multirow{2}{*}{$\begin{array}{l}\text { Hoşgörülï Davranma Alt } \\
\text { boyutu } \\
\text { 1. Başkalarının Yanlışlarına } \\
\text { ve Tercih. Tahammül Göster- } \\
\text { me }\end{array}$} & $\mathrm{K}_{1 Z}$ & 187 & 4,63 & 0,40 & \multirow[t]{2}{*}{3,01} & \multirow[t]{2}{*}{0,00} \\
\hline & Erkek & 193 & 4,48 & 0,54 & & \\
\hline \multirow{2}{*}{$\begin{array}{l}\text { Hoşgörülü Davranma Alt } \\
\text { boyutu } \\
\text { 2. Çevresindekilere Anlayışıl } \\
\text { Davranma }\end{array}$} & Kiz & 187 & 3,99 & 0,87 & \multirow[t]{2}{*}{2,62} & \multirow[t]{2}{*}{0,00} \\
\hline & Erkek & 193 & 3,73 & 0,98 & & \\
\hline Ölçekler & Kronik Hastalık & $\mathbf{n}$ & $\overline{\mathbf{X}}$ & Ss. & $\mathbf{t}^{\mathbf{a}}$ & $\mathbf{p}^{\mathrm{a}}$ \\
\hline \multirow{2}{*}{$\begin{array}{l}\text { Obez Çocuklara Yönelik Tu- } \\
\text { tum }\end{array}$} & Var & 29 & 4,65 & 1,04 & \multirow[t]{2}{*}{$-2,29$} & \multirow[t]{2}{*}{0,02} \\
\hline & Yok & 351 & 5,03 & 0,84 & & \\
\hline \multirow{2}{*}{$\begin{array}{l}\text { Obez Çocuklara Yönelik } \\
\text { Tutum Alt boyutu } \\
\text { 1.Obez Akranı Reddetme }\end{array}$} & Var & 29 & 4,76 & 1,23 & \multirow[t]{2}{*}{$-2,09$} & \multirow[t]{2}{*}{0,03} \\
\hline & Yok & 351 & 5,14 & 0,91 & & \\
\hline
\end{tabular}

a: Bağımsız gruplar t test, $\mathrm{p}<0.05$. 
Tablo 3. Öğrencilerin empati, hoşgörülü davranma ve obez çocuklara yönelik tutumlarının yaş gruplarına, sınıf düzeyine ve BKI'ye göre karşılaştırılması.

\begin{tabular}{|c|c|c|c|c|c|c|}
\hline Ölçekler & Yaş Grubu & $\mathbf{n}$ & $\overline{\mathbf{X}}$ & Ss. & $\mathbf{F}^{\mathbf{b}}$ & $\mathbf{p}^{\mathbf{b}}$ \\
\hline \multirow{3}{*}{$\begin{array}{l}\text { Hoşgörülü Davranma/ 1. Başkalarının } \\
\text { Yanlışlarına ve Tercih. Tahammül Gös- } \\
\text { terme }\end{array}$} & 9-10 yaş & 54 & 4,61 & 0,39 & \multirow[t]{3}{*}{4,58} & \multirow[t]{3}{*}{0,01} \\
\hline & 11-12 yaş & 196 & 4,61 & 0,46 & & \\
\hline & $13-14$ yaş & 130 & 4,45 & 0,54 & & \\
\hline Ölçekler & Sınıf Düzeyi & $\mathbf{n}$ & $\overline{\mathbf{X}}$ & Ss. & $\mathbf{F}^{\mathbf{b}}$ & $\mathbf{p}^{\mathbf{b}}$ \\
\hline \multirow{4}{*}{$\begin{array}{l}\text { Hoşgörülü Davranma/ 1. Başkalarının } \\
\text { Yanlışlarına ve Tercih. Tahammül Gös- } \\
\text { terme }\end{array}$} & 5. Sinif & 60 & 4,57 & 0,49 & \multirow[t]{4}{*}{2,72} & \multirow[t]{4}{*}{0,04} \\
\hline & 6. Sinif & 109 & 4,66 & 0,45 & & \\
\hline & 7.Sinif & 89 & 4,54 & 0,44 & & \\
\hline & 8.Sinif & 122 & 4,48 & 0,53 & & \\
\hline \multirow{4}{*}{$\begin{array}{l}\text { Obez Çocuklara Yönelik Tutum/ } 1 . \\
\text { Obez Akranı Reddetme }\end{array}$} & 5. Sinif & 60 & 5,04 & 0,89 & \multirow[t]{4}{*}{3,38} & \multirow[t]{4}{*}{0,01} \\
\hline & 6. Sinif & 109 & 4,91 & 1,08 & & \\
\hline & 7.Sinif & 89 & 5,16 & 0,94 & & \\
\hline & 8.Sinif & 122 & 5,29 & 0,80 & & \\
\hline Ölçekler & BKI & $\mathbf{n}$ & $\overline{\mathbf{X}}$ & Ss. & $\mathbf{F}^{\mathbf{b}}$ & $\mathbf{p}^{\mathbf{b}}$ \\
\hline \multirow[t]{5}{*}{ Hoşgörülü Davranma } & Çok zayıf & 30 & 4,57 & 0,08 & \multirow[t]{5}{*}{2,61} & \multirow[t]{5}{*}{0,03} \\
\hline & Zayif & 46 & 4,41 & 0,42 & & \\
\hline & Normal & 162 & 4,29 & 0,55 & & \\
\hline & Fazla kilolu & 90 & 4,23 & 0,53 & & \\
\hline & Obez & 52 & 4,17 & 0,55 & & \\
\hline \multirow{5}{*}{$\begin{array}{l}\text { Hoşgörüliü Davranma/ 1. Başkalarının } \\
\text { Yanlışlarına ve Tercih. Tahammül Gös- } \\
\text { terme }\end{array}$} & Çok zayıf & 30 & 4,73 & 0,32 & \multirow[t]{5}{*}{2,74} & \multirow[t]{5}{*}{0,02} \\
\hline & Zayif & 46 & 4,67 & 0,42 & & \\
\hline & Normal & 162 & 4,56 & 0,48 & & \\
\hline & Fazla kilolu & 90 & 4,50 & 0,48 & & \\
\hline & Obez & 52 & 4,43 & 0,59 & & \\
\hline
\end{tabular}

b: Tek Yönlü Varyans ( ANOVA), p<0,05; BKI: Beden Kitle Indeksi. 
Tablo 4. Öğrencilerin empati, hoşgörülü davranma ve obez çocuklara yönelik tutumları arasındaki ilişkinin değerlendirilmesi.

\begin{tabular}{|l|c|c|c|c|c|c|c|}
\hline & & $\mathbf{1}$ & $\mathbf{2}$ & $\mathbf{3}$ & $\mathbf{4}$ & $\mathbf{5}$ & $\mathbf{6}$ \\
\hline Empati (1) & & 1.00 & & & & & \\
\hline Hoşgörülü Davranma (2) & $\mathrm{r}$ & $0,8^{* *}$ & 1,00 & & & & \\
\hline $\begin{array}{l}\text { Başkalarının Yanlışlarına ve Tercihlerine } \\
\text { Saygı Gösterme (3) }\end{array}$ & $\mathrm{r}$ & $0,4^{* *}$ & $0,76^{* *}$ & 1,00 & & & \\
\hline Çevresindekilere Anlayışlı Davranma (4) & $\mathrm{r}$ & $0,36^{* *}$ & $0,84^{* *}$ & $0,29^{* *}$ & 1,00 & & \\
\hline Obez Çocuklara Yönelik Tutum (5) & $\mathrm{r}$ & $0,28^{* *}$ & $0,36^{* *}$ & $0,26^{* *}$ & $0,31^{* *}$ & 1,00 & \\
\hline Obez Akranı Reddetme (6) & $\mathrm{r}$ & $0,16^{* *}$ & $0,20^{* *}$ & $0,21^{* *}$ & $0,13^{*}$ & $0,74^{* *}$ & 1,00 \\
\hline Obez Akranı Kabul Etme (7) & $\mathrm{r}$ & $0,26^{* *}$ & $0,33^{* *}$ & $0,8^{* *}$ & $0,33^{* *}$ & $0,76^{* *}$ & $0,13^{* *}$ \\
\hline
\end{tabular}

r: Pearson korelasyon; *: $\mathrm{p}<0.01 ; * *: \mathrm{p}<0.00$. 